\title{
MOTIVASI, SIKAP, DAN INTENSI PENGGUNA MEDIA SOSIAL PADA KAMPANYE STOP ILLEGAL FISHING
}

\author{
La Moriansyah*)1 \\ *) Kementerian Kelautan dan Perikanan \\ Jl. Medan Merdeka Timor No.16 Jakarta Pusat
}

\begin{abstract}
Social media is commonly used to promote social campaigns, one of which is Stop Illegal Fishing campaign. To achieve success in this campaign, some conditions have to be fulfilled i.e. positive attitudes of the social media users toward the campaigns and high intentions to provide recommendations (word of mouth) to others. This study was conducted to analyze types of motivations affecting attitudes of users towards social campaigns (stop illegal fishing) in social media. In addition, it also analyzed the influence of attitudes on users' intentions in performing WOM. The method utilized to meet the objectives was Partial Least Square. The results showed that users' motivation in using social media and towards the campaign messages are perceived to have significantly a positive effect on the attitude towards social campaigns in social media. Besides, the increase in the intention to perform WOM is positively influenced by the attitudes of social media users. There are differences identified in the motivation that affect the attitudes of social media users towards campaign of the two groups i.e. the social media users who have never seen the Stop Illegal Fishing campaign (151 samples) and those who have seen the campaign in social media.
\end{abstract}

Keywords: motivation, attitude, word of mouth, user experience, uses and gratification theory, digital campaigns, social campaigns, stop illegal fishing

\begin{abstract}
ABSTRAK
Media sosial sering digunakan untuk mempromosikan kampanye sosial, contohnya adalah kampanye Stop Illegal Fishing. Untuk meraih kesuksesan pada kampanye ini, beberapa hal yang harus diraih adalah sikap positif pengguna media sosial terhadap kampanye dan intensi yang tinggi untuk memberikan rekomendasi (word of mouth) kepada orang lain. Penelitian ini dilakukan untuk menganalisis motivasi pengguna apa saja yang memengaruhi sikap pengguna media sosial terhadap kampanye sosial (stop illegal fishing) di media sosial. Selain itu menganalisis sikap pengguna berpengaruh pada intensi pengguna untuk melakukan WOM. Metode yang digunakan untuk menjawab tujuan adalah dengan metode Partial Least Square. Hasil penelitian menunjukkan motivasi pengguna untuk menggunakan media sosial dan terhadap pesan kampanye terbukti secara signifikan berpengaruh positif pada sikap pengguna terhadap kampanye sosial di media sosial. Selain itu peningkatan intensi untuk memberi WOM dipengaruhi secara positif oleh sikap pengguna media sosial. Terdapat perbedaan motivasi yang memengaruhi sikap pengguna media sosial terhadap kampanye pada dua kategori kelompok, yaitu pengguna media sosial yang belum pernah (151 sampel) dan pengguna media sosial yang pernah melihat kampanye Stop Illegal Fishing di media sosial.
\end{abstract}

Kata kunci: motivasi, sikap, word of mouth, pengalaman pengguna, teori uses \& gratification, kampanye digital, kampanye sosial, stop illegal fishing

\footnotetext{
${ }^{1}$ Alamat Korespondensi:

Email: lamoriano@gmail.com
} 


\section{PENDAHULUAN}

Media sosial merupakan salah satu media untuk melakukan kampanye digital (Williamson et al. 2010), dimana pengertian kampanye adalah suatu aktivitas yang dilakukan melalui suatu atau gabungan beberapa media menggunakan iklan, public relation, atau teknik interaktif lainnya, yang bertujuan untuk mempromosikan suatu produk, jasa, atau ide (Belch GE dan Belch MA, 2015). Hal ini disebabkan karena media sosial memiliki kemampuan untuk melakukan public engagement (Men and Tasi, 2015), berbagi informasi secara viral (Hutton and Fosdick, 2011), dan berbiaya rendah (Thackeray et al. 2008). Dengan kemampuan tersebut diharapkan dapat meningkatkan awareness terhadap kampanye tersebut secara lebih efektif. Pada penelitian Taylor et al. (2011) dijelaskan bahwa untuk meningkatkan persepsi atau sikap pengguna dalam menggunakan media sosial dapat dilakukan dengan cara mencocokan pesan pemasaran sesuai dengan kebutuhan atau motivasi pengguna dalam menggunakan media sosial. Jadi untuk menarik minat pengguna media sosial terhadap kampanye digital dan keinginan memberikan rekomendasi, maka pesan kampanye harus dapat disesuaikan dengan motivasi atau kebutuhan pengguna.

Menteri Kelautan dan Perikanan mengajak seluruh masyarakat Indonesia untuk ikut mengkampanyekan stop illegal fishing melalui media sosial (gresnews. com, 2014). Kampanye tersebut mangajak masyarakat untuk menghentikan dan mencegah kegiatan illegal fishing di wilayah laut Indonesia, hal ini termasuk dalam kategori kampanye sosial yang merupakan bagian dari ilmu social marketing. Menurut Kotler dan Lee (2011), social marketing adalah suatu proses yang menggunakan prinsip dan teknik pemasaran untuk mengkomunikasikan atau menyampaikan suatu nilai kepada target audiensi yang memberi manfaat terhadap masyarakat atau lingkungan, dan terhadap target audiensi ini sendiri. Oleh karena itu, dampak dari kampanye stop illegal fishing dapat menguntungkan bagi masyarkat umum dan khususnya masyarakat nelayan.

Dari sisi penelitian, telah banyak penelitian yang menggunakan uses and gratification theory untuk mengetahui motivasi atau alasan penggunaan media sosial dan memengaruhi sikap pengguna terhadap digital advertising, aplikasi mobile, dan situs media sosial itu sendiri (Ha et al. 2014; Taylor et al. 2011;
Celebi, 2015; Lien dan Cao, 2014). Namun, menurut penelusuran penulis dari periode 2008-2015, belum terdapat penelitian yang meneliti tentang hubungan motivasi untuk menggunakan media sosial dengan sikap pengguna terhadap kampanye sosial. Di lain pihak terdapat penelitian mengenai kesuksesan kampanye sosial dengan menggunakan media sosial, yaitu penelitian Chung (2015) dilakukan penelitian terhadap kampanye sosial (anti-smoking) dengan menggunakan Youtube sebagai media kampanye.

Kampanye sosial termasuk dalam kategori social marketing, dimana nilai yang dikomunikasikan memiliki manfaat untuk masyarakat dan lingkungan. Oleh sebab itu, untuk dapat mencapai kesuksesan pada kampanye sosial di media sosial, diharapakan pesan kampanye tersebut dapat memenuhi kebutuhan pengguna dalam menggunakan media sosial sehingga mendapatkan sikap positif dari pengguna. Selain itu meningkatkan intensi untuk memberikan rekomendasi word of mouth (WOM) sangat penting, sehingga kampanye tersebut dapat disebarkan dengan viral marketing, baik melalui Tradisional word of mouth atau electronic word of mouth (e-WOM). Berikutnya perlu dianalisis perbedaan motivasi berdasarkan pengalaman pengguna, yaitu antara pengguna yang belum pernah dan sudah pernah melihat kampanye sosial di media sosial. Karena perbedaan pengalaman pengguna media sosial berpengaruh terhadap sikap dan perilaku pengguna dalam meggunakan media sosial (Chang dan Zhu, 2011) sehingga tim kampanye dapat merumuskan strategi yang digunakan untuk mendapatkan pendukung baru (acquiring) dan mempertahankan pendukung yang sudah ada (retention).

Penelitian ini dilakukan untuk menganalisis motivasi pengguna apa saja yang memengaruhi sikap pengguna media sosial terhadap kampanye sosial (stop illegal fishing) di media sosial. Selain itu menganalisis sikap pengguna berpengaruh pada intensi pengguna untuk melakukan WOM. Dimana WOM dapat dikategorikan menajadi Tradisional WOM dan e-WOM.

Definisi WOM adalah pertukaran atau alur informasi, komunikasi atau pembicaraan antara dua individu (Goyette et al. 2010). Komunikasi WOM dapat dilakukan dengan tatap muka secara langsung, telepon, email, atau media komunikasi lainnya. Dengan teknologi internet yang terus berkembang, berbagi informasi, seperti foto, video, atau artikel, yang sebelumnya dilakukan pada Web Sites tertentu, pada saat ini sudah 
bermigrasi ke media sosial (Hutton dan Fosdik, 2011). Selain itu, konsumen mempercayai rekomendasi yang didapatkan melalui WOM, dimana sebagian besar mendapatkan rekomendasi tersebut secara online (Kassim dan Abdullah, 2010). Menurut King, Racherla, dan Bush (2014) motivasi seseorang untuk memberikan WOM diantaranya dipengaruhi oleh faktor pesan dan karakter sosial orang tersebut, dijelaskan juga bahwa faktor pesan dipengaruhi berdasarkan bagaimana pesan tersebut dikomunikasikan dan media yang digunakan. Oleh sebab itu, pesan tersebut harus dikomunikasikan dengan sesuai dan pada media yang tepat, sehingga mendapatkan sikap yang positif dari individu yang membaca pesan tersebut. Karena sikap positif memengaruhi individu untuk memberikan WOM yang positif (Ha et al. 2015; Lien dan Cao, 2014).

Beberapa teori mendukung terkait media sosial antara lain Kaplan dan Haenlin (2010) mendefinisikan Media Sosial adalah suatu grup aplikasi berbasis internet yang menggunakan ideologi dan teknologi Web 2.0, dimana pengguna dapat membuat atau bertukar informasi pada aplikasi tersebut. Beberapa media sosial yang sangat digemari dan memiliki jutaan pengguna di Indonesia adalah Facebook, Twitter, Google+, LinkedIn, Instagram, dan Pinterest (Kemp, 2015). Sebelumnya untuk berbagi informasi, seperti foto, video, atau artikel dilakukan pada web sites tertentu, namun pada saat ini sudah bermigrasi ke media sosial (Hutton dan Fosdik, 2011). Selain itu media sosial memiliki beberapa perbedaan dengan media komunikasi pemasaran lainya, yaitu always on dan everywhere (Powers et al. 2012). Keutamaanya adalah pengguna media sosial dapat menggakses kapan saja dan dimana saja, karena selain dapat diakses melalui komputer, media sosial juga dapat diakses melalui mobile/smart phone. Hal tersebut yang memberikan peluang bagi para pemasar untuk dapat melakukan komunikasi pemasaran.

Selanjutnya, dikarenakan kelebihan dalam melakukan komunikasi dan berbagi informasi, media sosial merupakan salah satu media untuk melakukankampanye digital, contoh yang populer adalah kesukesan kampanye digital Presiden Barrack Obama ketika pemilu presiden Amerika Serikat (Williamson et al. 2010). Menurut Wigstrom dan Wigmo (2011), terdapat beberapa faktor yang memengaruhi meningkatkan awareness di media sosial, salah satunya adalah pesan atau advertising tersebut harus dapat menarik perhatian konsumen, dan mampu mengajak konsumen untuk ikut berpartisipasi. Oleh karena itu, untuk meningkatkan efektivitas kampanye sosial perlu diketahui faktorfaktor yang memengaruhi sikap pengguna media sosial terhadap pesan kampanye sosial, dan intensi untuk memberikan rekomendasi mengenai kampanye tersebut kepada pengguna lain, sehingga pengguna media sosial tertarik untuk berkomunikasi dan berbagi informasi mengenai kampanye digital tersebut.

Media Uses and Gratification Theory ini menjelaskan bahwa seseorang secara aktif mencari media tertentu dan muatan (isi) tertentu untuk menghasilkan kepuasan (atau hasil) tertentu (Katz et al. 1974). Aplikasi teori tersebut pada media sosial sangat relevan karena teori tersebut berasal dari literatur komunikasi, dimana kemampuan media sosial adalah memungkinkan pengguna untuk melakukan komunikasi dengan jutaan pengguna lainnya (Williams et al. 2012). Oleh sebab itu, teori tersebut dapat digunakan untuk mengetahui motivasi individu dalam menggunakan media sosial. Sebelumnya teori tersebut telah diaplikasikan untuk mengetahui motivasi pada penggunaan internet, online advertising, komunitas virtual, mobile advertising, dan media sosial (Taylor et al. 2011). Selain itu Lien dan Cao (2013), menggunakan teori uses and gratification untuk mengetahui motivasi penggunaan aplikasi WeChat. Pada Tabel 1 akan dijelaskan secara ringkas penelitian sebelumnya yang melakukan penelitian tentang pengaruh motivasi penggunaan media social terhadap sikap pengguna sebagai berikut:

Dari Tabel 1 peneliti menggunakan beberapa motivasi yang dianalisis sebagai faktor yang memengaruhi sikap pengguna terhadap kampanye sosial, yaitu motivasi informative, entertainment, self-brand congruity, peer influenced, quality of life, structure time, convinience, dan privacy concern. Menurut Lassus (2003) attitude atau sikap memiliki definisi suatu ekspresi/sikap dari hasil evaluasi terhadap suatu entitas yang menghasilkan tingkat kesukaan atau ketidaksukaan, dengan kata lain adalah penilaian individu terhadap suatu hal, seperti produk, orginasasi, merek, atau topik. Dalam buku Solomon (2013) bahwa sikap dibangun berdasarkan pengalaman dan pembelajaran dalam kurun waktu tertentu, selain itu sikap juga dapat berubah-ubah, umumnya perubahan tersebut terjadi secara perlahanlahan, pemasar dapat melakukan perubahan sikap dengan cara melakukan komunikasi pemasaran. Berdasarkan Theory of Reasoned Action dari Ajzen dan Fishbein (1980), sikap positif dapat mengarah kepada 
melakukan suatu tindakan atau perilaku, sebaliknya sikap negatif akan mengarah kepada menghindari suatu tindakan atau perilaku.

\section{METODE PENELITIAN}

Pada penelitian ini penulis ingin menganalisis bahwa motivasi individu untuk menggunakan media sosial dan motivasi terhadap pesan kampanye dapat berpengaruh terhadap sikap pengguna untuk kampanye sosial di media sosial. Hal tersebut berdasarkan penjelasan Taylor et al. (2011) bahwa untuk mendapatkan sikap yang baik pesan pemasaran harus dapat memenuhi motivasi pengguna untuk menggunakan media sosial. Selain itu dijelaskan juga dalam buku Solomon (2013), apabila motivasi individu dapat terpenuhi, makan akan memengaruhi emosi individu tersebut. Dimana emosi dapat membentuk sikap dari individu. Buku ini juga menjelaskan konsep sikap (attitude), yang menjelaskan bahwa sikap suatu individu dipengaruhi oleh beberapa faktor, salah satunya adalah pesan pemasaran.

Dalam penelitian ini juga ingin menganalisis bahwa sikap pengguna media sosial dapat memengaruhi intensi individu untuk memberikan WOM, baik tradisional WOM (offline WOM) dan e-WOM (online WOM). Hal tersebut berdasarkan penjelasan Thackeray et al. (2008) bahwa media sosial merupakan media yang sangat efektif untuk melakukan kampanye sosial, salah satu alasanya adalah kemampuan viral marketing pada media sosial yang menggunakan WOM. Untuk mendorong pengguna media sosial melakukan WOM, maka pengguna sosial harus memiliki sikap yang positif terhadap kampanye sosial tersebut. Karena sikap positif pengguna berpengaruh untuk melanjutkan pesan viral marketing (Camarero dan San Jose, 2011; Huang et al. 2013).

Tabel 1. Penelitian tentang motivasi penggunaan media sosial berdasarkan uses \& gratification theory

\begin{tabular}{|c|c|c|c|c|}
\hline Penulis & Tahun & Independent (Motivasi) & Dependent & Komparasi \\
\hline Krisanic & 2008 & $\begin{array}{l}\text { Entertainment, connect with other, } \\
\text { shopping, product enquiry }\end{array}$ & $\begin{array}{l}\text { Attitude toward facebook } \\
\text { use, Behaviour to } \\
\text { advertising }\end{array}$ & Tidak \\
\hline Barker & 2009 & $\begin{array}{l}\text { Peer group contact, pass time, } \\
\text { entertainment, social identity, social } \\
\text { compensation, learning, self-esteem }\end{array}$ & SNS use & $\begin{array}{l}\text { Perbandingan } \\
\text { perbedaan jenis } \\
\text { kelamin }\end{array}$ \\
\hline $\begin{array}{l}\text { Chung dan } \\
\text { Austria }\end{array}$ & 2010 & Informative, entertainment, Interaction & $\begin{array}{l}\text { Attitude to online } \\
\text { Shopping messages in } \\
\text { Social Media }\end{array}$ & Tidak \\
\hline Taylor et al. & 2011 & $\begin{array}{l}\text { Infromative, entertainment, self-brand } \\
\text { congruity, peer influence, quality of time, } \\
\text { structure time, invasiveness, privacy } \\
\text { concern }\end{array}$ & $\begin{array}{l}\text { Attitude to social media } \\
\text { advertising }\end{array}$ & Tidak \\
\hline Kim et al. & 2011 & $\begin{array}{l}\text { Seeking friend, social support, } \\
\text { information, entertainment, convenience }\end{array}$ & $\begin{array}{l}\text { Attitude to social } \\
\text { networking sites }\end{array}$ & $\begin{array}{l}\text { Perbandingan } \\
\text { perbedaan kultur }\end{array}$ \\
\hline Chang dan Zhu & 2011 & $\begin{array}{l}\text { Information, entertainment, connect } \\
\text { with friend, meeting with new people, } \\
\text { conformity }\end{array}$ & $\begin{array}{l}\text { Attitude to adoption of } \\
\text { social networking sites }\end{array}$ & $\begin{array}{l}\text { Perbandingan } \\
\text { perbedaan } \\
\text { pengalaman }\end{array}$ \\
\hline Lien dan Cao & 2014 & Entertainment, sociality, information & Attitude toward WeChat & Tidak \\
\hline Ha et al. & 2015 & $\begin{array}{l}\text { Conitive, hedonic, integrative, social } \\
\text { interaction, mobile convenience }\end{array}$ & $\begin{array}{l}\text { Attitude to mobile Social } \\
\text { networking Sites }\end{array}$ & $\begin{array}{l}\text { Perbandingan } \\
\text { mobile Facebook } \\
\text { dan KakaoTalk }\end{array}$ \\
\hline \multirow[t]{2}{*}{ Celebi } & 2015 & $\begin{array}{l}\text { Information, entertainment, privacy } \\
\text { concern, quality of life, peer influence, } \\
\text { structured time, social-brand congruity }\end{array}$ & $\begin{array}{l}\text { Attitude to facebook } \\
\text { advertising }\end{array}$ & Tidak \\
\hline & & $\begin{array}{l}\text { Pass time, interpersonal, information, } \\
\text { entertainment, convenience }\end{array}$ & $\begin{array}{l}\text { Attitude to internet } \\
\text { advertising }\end{array}$ & Tidak \\
\hline
\end{tabular}


Perbedaan motivasi pengguna dalam menggunakan media sosial yang memengaruhi sikap untuk kampanye sosial, antara pengguna yang sudah pernah dan belum pernah melihat kampanye sosial di media sosial. Hal tersebut berdasarkan penelitian Chang dan Zhu (2011) yang menjelaskan bahwa terdapat perbedaan motivasi pengguna yang memengaruhi sikap terhadap penggunaan media sosial berdasarkan kelompok yang berbeda pengalaman (pre-adopters dan post-adopters). Dengan mengetahui perbedaan motivasi pengguna media sosial terhadap media sosial dan pesan kampanye, maka pesan kampanye sosial dapat dirumuskan sesuai motivasi pengguna tersebut.

Sampel pada penelitian ini adalah para pengguna Media Sosial di Indonesia. Sampel dibedakan menjadi dua kelompok berdasarkan pengalamannya (experience) terhadap kampanye stop illegal fishing di media sosial, yaitu kelompok pengguna yang belum pernah melihat kampanye tersebut dan kelompok yang sudah pernah melihat kampanye tersebut. Dalam penelitian ini kelompok yang belum pernah melihat kampanye stop illegal fishing di media sosial akan diperlihatkan beberapa gambar kampanye tersebut di media sosial, gambar tersebut akan diperlihatkan ketika mengisi kuesioner. Hal tersebut bertujuan untuk memberikan gambaran kepada responden tentang kampanye stop illegal fishing. Sedangkan untuk kelompok yang sudah pernah melihat kampanye, tidak diperlihatkan gambar kampanye, akan tetapi langsung menjawab pertanyaan di kuesioner.

Sebelum dilakukan pengambilan data alat ukur (kuesioner) terlebih dahulu dilakukan face validity yang bertujuan untuk mengevaluasi pertanyaanpertanyaan pada kuesioner dapat dimengerti dengan baik oleh para responden sehingga jawaban yang akan diberikan sesuai untuk mengukur variabel konstruk dalam penelitian ini. Metode pengumpulan data dalam penelitian ini menggunakan metode single cross sectional, dimana metode pengumpulan data yang digunakan untuk memperoleh data primer dilakukan dengan cara kuesioner online, kuesioner disebar menggunakan internet secara viral dengan mengirim tautan kuesioner melalui email, online messaging, dan media sosial. Dengan jangka waktu 20 hari (2-21 Oktober 2015). Skala pengukuran variabel yang digunakan adalah 7 -Likert scale $(1=$ sangat tidak setuju sekali, 7 = sangat setuju sekali). Untuk mengukur variabel konstruk pada penelitian ini, digunakan indikator yang diadaptasi dari penelitian sebelumnya.
Dimana variabel informative, entertainment, self-brand congruity, peer influence, quality of life, structure time, privacy concern, dan attitude toward digital campaign diadaptasi dari penelitian Taylor et al. (2011). Variabel convenience diadaptasi dari penelitian Ha et al. (2015) dan Papacharissi dan Rubin (2000). Selain itu online WOM diadaptasi dari Mikalef et al. (2012) dan offline WOM diadaptasi dari Goyette et al. (2010).

Pada penelitian ini terdapat tiga tahapan dalam mengolah data. Tahap pertama adalah analisis diskriptif menggunakan aplikasi SPSS. Kedua, melakukan analisis model struktural untuk melihat signifikansi keterkaitan antara variabel menggunakan metode PLS dengan aplikasi smartPLS 2. Terakhir untuk menganalisis perbedaan antara dua kategori sampel, digunakan metode multi-group analysis.

Responden dalam penelitian ini berjumlah 353 sampel, dan dikategorikan berdasarkan kelompok responden yang belum pernah melihat $(\mathrm{n}=151)$ dan pernah melihat $(\mathrm{n}=202)$ kampanye stop illegal fishing di media sosial. Profil sampel pada penelitian ini dijelaskan pada secara ringkas pada Tabel 2. Berdasarkan penjelasan tersebut maka dibangun kerangka konseptual penelitian pada Gambar 1 yang diadaptasi dari penelitian Taylor et al. (2011). Karena dalam penelitian tersebut dijelaskan beberapa motivasi penggunaan media sosial yang digunakan sebagai faktor yang memengaruhi sikap konsumen terhadap pesan komersil atau iklan di media sosial, sehingga dalam penelitian ini model tersebut dapat diadaptasi untuk mengetahui motivasi penggunaan media sosial apa saja yang berpengaruh terhadap sikap pengguna pada kampanye sosial. Namun model penelitian Taylor et al. (2011), tidak menjelaskan tentang WOM. Konsep WOM yang digunakan untuk melakukan viral marketing. Oleh sebab itu dalam penelitian ini ditambahkan pengaruh sikap pengguna terhadap intensi pengguna untuk memberikan rekomendasi (WOM), baik secara offline WOM dan online WOM.

\section{Hipotesis Penelitian}

Dalam konteks media sosial, para pengguna memiliki motivasi untuk menggunakan media sosial adalah untuk mencari informasi atau hiburan (AdReaction, 2010). Selain itu penelitian Taylor et al. (2011) menjelaskan bahwa motivasi informative berpengaruh positif terhadap sikap pengguna kepada pesan advertising di media sosial. Sama halnya dalam penelitian Ducoffe 
(1996), faktor informative memiliki pengaruh positif terhadap sikap pengguna media sosial untuk iklan komersil di internet, demikian juga sikap positif pengguna terhadap aplikasi WeChat dipengaruhi oleh motivasi untuk mencari informasi (Lien dan Cao, 2013). Selain itu sikap pengguna terhadap pesan pemasaran di media sosial dipengaruhi oleh faktor informatif dari pesan tersebut (Chung dan Austria, 2010), dan pada sikap pengguna terhadap internet advertising dan facebook advertising dipengaruhi oleh kebutuhan akan mencari informasi (Celebi, 2015). Berdasarkan hasil penelitian yang ada, maka diformulasikan hipotesis H1: Motivasi informative berpengaruh positif terhadap sikap pengguna media sosial pada kampanye digital.

Dalam penelitian Taylor et al. (2011) menjelaskan bahwa motivasi entertainment memberi pengaruh positif terhadap sikap pengguna untuk pesan advertising di media sosial. Pada penelitian Celebi (2015) juga dijelaskan bahwa sikap pengguna terhadap Facebook advertising dipengaruhi oleh kebutuhan pengguna akan mencari hiburan. Demikian juga sikap positif pengguna terhadap aplikasi WeChat dipengaruhi oleh motivasi untuk mencari hiburan (Lien dan Cao, 2013). Para pengguna Facebook juga dipengaruhi motivasi untuk mencari hiburan, sehingga berpengaruh terhadap sikap positif pengguna dalam menggunakan situs Facebook (Krisanic, 2008). Berdasarkan hasil penelitian yang ada, maka diformulasikan hipotesis H2: Motivasi entertainment berpengaruh positif terhadap sikap pengguna media sosial pada kampanye digital.

Sikap pengguna yang mengekspresikan dirinya dalam merespon pesan di media sosial dapat diartikan sebagai identifikasi terhadapa dirinya (Wojnicki dan Godes, 2008). Apabila pengguna merasa pesan yang disampaikan sesuai dengan identifikasi dirinya maka akan meningkatkan sikap positif terhadap pesan tersebut (Celebi, 2015). Dalam penelitian Taylor et al. (2011) dijelaskan bahwa motivasi self-brand congruity berpengaruh positif terhadap sikap pengguna untuk pesan advertising di media sosial. Oleh karena itu dapat disimpulkan jika pesan kampanye sosial sesuai dengan identifikasi diri pengguna, maka pengguna akan bersifat positif terhadap kampanye sosial tersebut. Berdasarkan hasil penelitian yang ada, maka diformulasikan hipotesis H3: Motivasi self-brand congruity berpengaruh positif terhadap sikap pengguna media sosial pada kampanye digital.

Tabel 2. Profil responden $(n=353)$

\begin{tabular}{|c|c|c|c|c|}
\hline \multirow{2}{*}{\multicolumn{2}{|c|}{ Profil responden }} & \multicolumn{2}{|c|}{ Kategori responden } & \multirow{3}{*}{$\begin{array}{c}\text { Total } \\
145\end{array}$} \\
\hline & & \multirow{2}{*}{$\begin{array}{c}\text { Belum pernah } \\
91(60,3 \%)\end{array}$} & \multirow{2}{*}{$\begin{array}{c}\text { Sudah pernah } \\
54(26,7 \%)\end{array}$} & \\
\hline Jenis kelamin & Wanita & & & \\
\hline & Pria & $60(39,7 \%)$ & $148(73,3 \%)$ & 208 \\
\hline Umur & Rata-rata & 26 Tahun & 31 Tahun & 29 Tahun \\
\hline \multirow[t]{4}{*}{ Tingat pendidikan } & SLTA atau Setara & $41(27,2 \%)$ & $42(20,8 \%)$ & 83 \\
\hline & DIPLOMA atau Setara & $10(6,6 \%)$ & $25(12,4 \%)$ & 35 \\
\hline & SARJANA atau Setara & $82(54,3 \%)$ & $108(53,5 \%)$ & 190 \\
\hline & MASTER atau Setara & $18(11,9 \%)$ & $27(13,4 \%)$ & 45 \\
\hline \multirow[t]{6}{*}{ Media sosial } & Facebook & $57(37,7 \%)$ & $130(64,4 \%)$ & 187 \\
\hline & Twitter & $11(7,3 \%)$ & $13(6,4 \%)$ & 24 \\
\hline & Instagram & $50(33,1 \%)$ & $21(10,4 \%)$ & 71 \\
\hline & Youtube & $17(11,3 \%)$ & $9(4,5 \%)$ & 26 \\
\hline & Path & $13(8,6 \%)$ & $7(3,5 \%)$ & 20 \\
\hline & Lainnya & $3(2 \%)$ & $22(10,8 \%)$ & 25 \\
\hline \multirow{2}{*}{$\begin{array}{l}\text { Pekerjaan terkait } \\
\text { perikanan }\end{array}$} & Terkait & $18(11,9 \%)$ & $110(54,5 \%)$ & 128 \\
\hline & & $133(88,1 \%)$ & $92(45,5 \%)$ & 225 \\
\hline \multicolumn{2}{|c|}{ Jumlah sampel (n) } & $151(43 \%)$ & $202(57 \%)$ & 353 \\
\hline
\end{tabular}




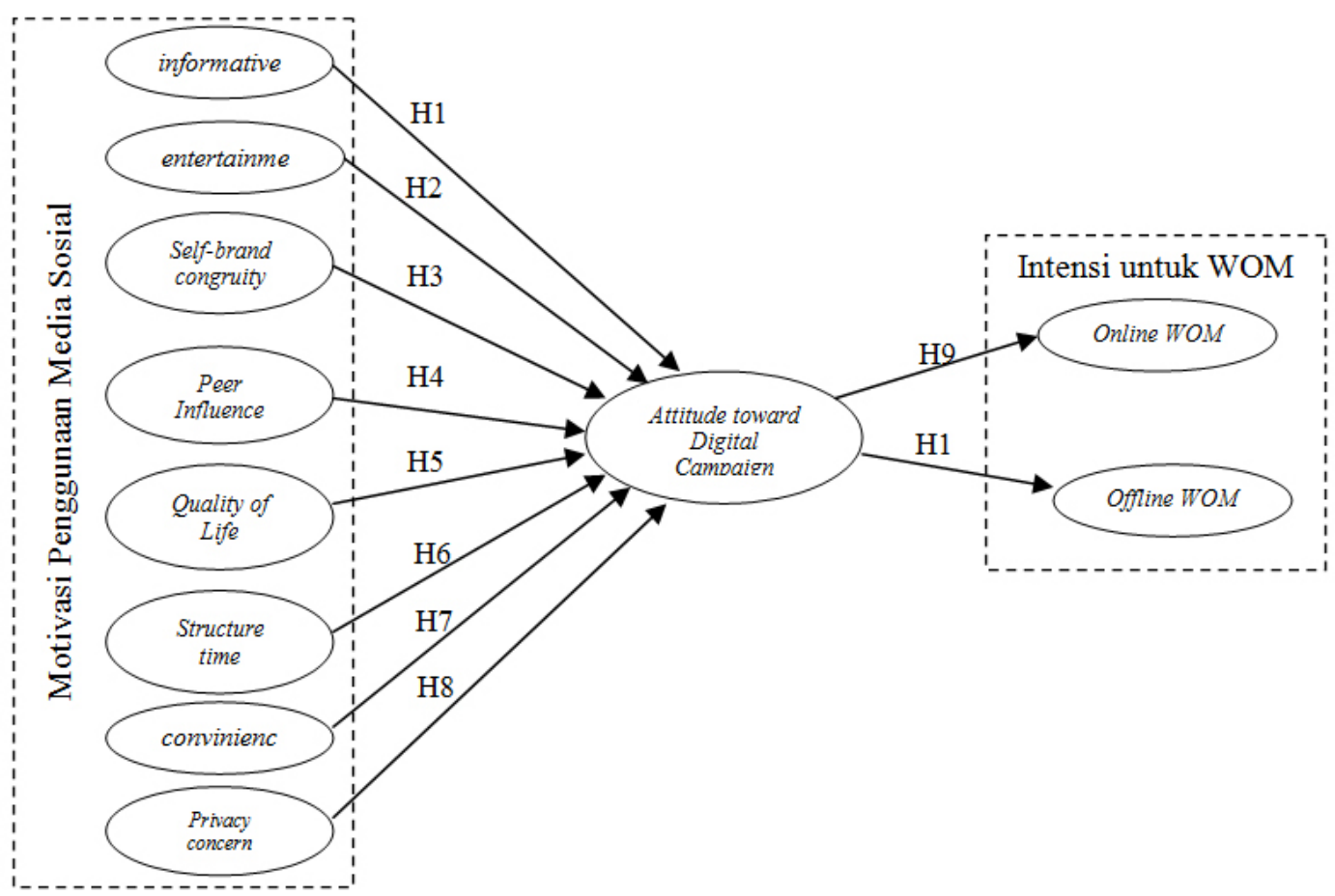

Gambar 1. Kerangka pemikiran penelitian

Dalam penelitian Taylor et al. (2011) dijelaskan bahwa motivasi peer influenced berpengaruh positif terhadap sikap pengguna untuk pesan advertising di media sosial. Dijelaskan juga bahwa motivasi untuk berinteraksi memberi pengaruh positif terhadap sikap pengguna untuk pesan pemasaran di media sosial (Chung dan Austria, 2010). Selain itu kebutuhan untuk berinterkasi memengaruhi sikap pengguna terhadap aplikasi KakaoTalk (Ha et al. 2015). Demikian juga dalam aplikasi mobile KakaoTalk, sikap positif para pengguna terhadap aplikasi tersebut dipengaruhi oleh motivasi pengguna untuk berinterakasi sosial (Kim et al. 2011). Pada kampanye Anti-smoking di Youtube, faktor peer influenced menjadi salah satu faktor yang membuat sukses kampanye tersebut (Chung, 2015). Pada saat berinterkasi mengenai kampanye sosial dengan teman atau keluarga di media sosial diharapkan dapat memberi pengaruh positif terhadap sikap pengguna untuk kampanye sosial tersebut. Hasil penelitian yang ada, maka diformulasikan hipotesis H4: Motivasi peer influence berpengaruh positif terhadap sikap pengguna media sosial pada kampanye digital.

Menurut Whiting dan Williams (2013), salah satu motivasi menggunakan media sosial adalah untuk mengisi waktu luang dan relaksasi. Karena sifat media sosial yang always on dan mobile dapat mendukung kebutuhan pengguna untuk mengisi waktu luang dan relaksasi (Powers et al. 2012). Dijelaskan bahwa faktor quality of life berpengaruh secara positif pada sikap pengguna terhadap Facebook advertising (Celebi, 2015). Berdasarkan hasil penelitian yang ada, maka diformulasikan hipotesis H5: Motivasi quality of life berpengaruh positif terhadap sikap pengguna media sosial pada kampanye digital.

Menurut Powers et al. (2012) salah satu sifat media sosial, yaitu Always On, dimana dapat mengubah pengguna dari pembelanja pasif menjadi pembelanja aktif. Hal tersebut disebabkan oleh informasi dan exposure yang didapatkan pengguna secara rutin (Taylor et al. 2011). Dijelaskan bahwa faktor structure time berpengaruh secara positif pada sikap pengguna terhadap Facebook advertising (Celebi, 2015). Oleh sebab itu dapat disimpulkan bahwa dengan melihat pesan kampanye sosial tersebut secara rutin di media sosial, maka akan memengaruhi sikap pengguna terhadap kampanye sosial. Hasil penelitian yang ada, maka diformulasikan hipotesis H6: Motivasi structure time berpengaruh positif terhadap sikap pengguna media sosial pada kampanye digital.

Dalam perbandingan dua buah kultur yang berbeda antara mahasiswa Amerika dan Korea, dijelaskan bahwa motivasi kenyamanan berpengaruh positif pada sikap mahasiswa Amerika dan Korea terhadap situs media sosial (Kim et al. 2011). Selain itu Ko et al. (2005) menjelaskan bahwa kenyamanan merupakan motivasi dasar dari penggunaan aplikasi internet. Dijelaskan juga bahwa motivasi kenyamanan dalam 
aplikasi mobile juga berpengaruh positif terhadap sikap pengguna untuk menggunakan aplikasi tersebut (Ha et al. 2014). Di lain pihak jika pengguna merasa kenyamanannya terganggu oleh pesan di media sosial, maka pengguna akan bersifat negatif terhadap pesan tersebut (Taylor et al. 2011). Diharapkan kampanye sosial di media sosial dapat memberikan kenyamanan bagi para pengguna dengan tujuan mendapatkan sikap positif pengguna. Berdasarkan hasil penelitian yang ada, maka diformulasikan hipotesis H7: Motivasi convenience berpengaruh positif terhadap sikap pengguna media sosial pada kampanye digital.

Perasaan aman pada informasi privasi pengguna akan berpengaruh positif terhadap sikap pada Facebook advertising (Celebi, 2015). Di lain pihak, dijelaskan bahwa gangguan dan ketidak amanan pada privacy concern akan memengaruhi sikap negatif terhadap pesan advertising di media sosial (Taylor et al. 2011). Selain itu online advertising yang memiliki keamanan rendah akan informasi privasi, pengguna akan membuat sikap negatif terhadap online advertising tersebut (Stanaland et al. 2011). Oleh sebab itu diharapakan kampanye sosial dapat menjaga keamanan dari informasi priviasi pengguna untuk mendapatkan sikap positif. Berdasarkan hasil penelitian yang ada, maka diformulasikan hipotesis H8: Motivasi privacy concern berpengaruh positif terhadap sikap pengguna media sosial pada kampanye digital.

Berdasarkan disertasi Chu (2009) dijelaskan perbedaan dari Tradisional WOM dan e-WOM diantarnya adalah cara penyampaian WOM, batasan atau cakupan WOM, dan kecepatan WOM. Pertama pada Tradisional WOM disampaikan dengan cara komunikasi secara langsung, sedangkan pada e-WOM dilakukan dengan menggunakan fungsi yang tedapat pada situs media sosial. Berikutnya Tradisional WOM sangat terbatas oleh batasan geografis dan waktu, sedangkan pada e-WOM tidak pada batasan geografis dan waktu karena menggunakan media internet. Terakhir, kecepatan Tradisional WOM lebih lambat dibandingkan dengan kecepatan e-WOM dalam menyebarkan berita, karena komunikasi Tradisional WOM menggunakan komunikasi one-one sedangkan pada e-WOM dapat dilakukan komunikasi one-many. Berdasarkan hasil penelitian yang telah ada, maka diformulasikan hipotesis H9: Sikap terhadap kampanye digital berpengaruh positif terhadap intensi melakukan WOM (offline WOM) dan H10: Sikap terhadap kampanye digital berpengaruh positif terhadap intensi melakukan e-WOM (online WOM).

Dalam penelitian Chang dan Zou (2011) dijelaskan bahwa terdapat perbedaan faktor yang memengaruhi sikap dan intensi penggunaan media sosial antara preadopters dan post-adopters. Selain itu sikap pengguna terhadap suatu tekhnologi informasi dapat berbeda berdasarkan pengalaman yang dimiliki pengguna, seperti individu yang sudah pernah menggunakan tekhnologi tersebut dan yang berlum pernah menggunakannya (Karahanna et al. 1999). Oleh sebab itu, berdasarkan pengalaman pengguna terhadap kampanye sosial di media sosial, maka dibentuklah hipotesis sebagai berikut H11: Terdapat perbedaan motivasi pengunaan media sosial yang memengaruhi sikap pengguna terhadap kampanye digital antara pengguna yang belum pernah melihat dan yang sudah pernah melihat kampanye digital.

\section{HASIL}

Dari hasil analisis model pengukuran (outer model) seluruh variabel memiliki tingkat validasi dan reliabilitas yang baik. Dimana nilai average variance extracted (AVE) seluruh variabel lebih besar dari 0,5, nilai cronbach alpha lebih besar dari 0,7, dan Composite Reliability lebih besa dari 0,7 (Hair et al. 2006). Secara ringkas hasil analisis model pengukuran dijelaskan pada Tabel 3 .

Model struktural bertujuan melihat signifikansi keterkaitan antar variabel dan parameter jalur yang sesuai dengan rerangka konseptual penelitian, dengan menggunakan nilai $\mathrm{t}(\mathrm{t} \geq 1,64$ : signifikan) pada tingkat kekeliruan 5\% ( $<00,05$ : one-tailed) (Ghozali, 2006). Adapun untuk tingkat kekeliruan 1\% ( $<<0,01$ : onetailed) menggunakan nilai $\mathrm{t} \geq 2,32$ (signifikan). Selain itu untuk melihat arah hubungan tersebut berpengaruh positif atau negatif maka digunakan nilai dari Standarize Coefficient ( $\beta$ ). Jika nilai $\beta$ positif maka arah hubungan tersebut positif, begitu juga sebaliknya. Oleh karena itu, model sturktural digunakan untuk melakukan uji hipotesis $1-10$ pada kedua kelompok. Hasil uji analisis Model Struktural hipotesis selengkapnya pada Tabel 4. 
Selanjutnya pada uji H11 dilakukan analisis multi group analysis. Pertama dilakukan uji chi square difference dengan menggunakan aplikasi AMOS, yang menghasilkan nilai $(\Delta \chi 2=92218, \Delta d f=39, p=0.000)$. Dari hasil tersebut dijelaskan bahwa model struktural kedua kelompok berbeda secara signifikan. Setelah itu dilakukan perbandingan pada masing-masing hubungan (path), hal tersebut dilakukan menggunakan nilai $\mathrm{t}$ yang didapat dengan cara membandingkan jumlah sampel, standar deviasi, dan rerata dari masing-masing kelompok sampel (Lowry dan Gaskin, 2014). Dari hasil analisis tersebut terdapat satu hubungan yang memiliki nilai $\mathrm{t}$ diatas 1,96 , yaitu hubungan antara motivasi convenience terhadap sikap pengguna pada kampanye sosial. Dari hasil penjelasan diatas makan disimpulkan bahwa H11 diterima.

Tabel 3. Hasil analisis model pengukuran (outer model)

\begin{tabular}{lcccccc}
\hline \multirow{2}{*}{ Variabel } & \multicolumn{3}{c}{ Belum pernah $(\mathrm{n}=151)$} & \multicolumn{3}{c}{ Sudah pernah $(\mathrm{n}=202)$} \\
\cline { 2 - 7 } & AVE $(\geq 0,5)$ & $\begin{array}{c}\text { Cronbach } \\
\text { Alpha }(\geq 0,5)\end{array}$ & $\begin{array}{c}\text { Composite } \\
\text { Reliability } \\
(\geq 0,7)\end{array}$ & AVE $(\geq 0,5)$ & $\begin{array}{c}\text { Cronbach } \\
\text { Alpha }(\geq 0,5)\end{array}$ & $\begin{array}{c}\text { Composite } \\
\text { Reliability } \\
(\geq 0,7)\end{array}$ \\
\hline Informative & 0,78 & 0,86 & 0,92 & 0,74 & 0,83 & 0,89 \\
Entertainment & 0,73 & 0,87 & 0,91 & 0,63 & 0,73 & 0,87 \\
Self-Brand Congruity & 0,63 & 0,71 & 0,83 & 0,71 & 0,79 & 0,88 \\
Peer Influence & 0,64 & 0,89 & 0,91 & 0,53 & 0,82 & 0,87 \\
Quality of Life & 0,66 & 0,73 & 0,85 & 0,71 & 0,82 & 0,88 \\
Structured Time & 0,62 & 0,85 & 0,89 & 0,59 & 0,84 & 0,88 \\
Convenience & 0,64 & 0,81 & 0,88 & 0,65 & 0,73 & 0,85 \\
Privacy Concern & 0,81 & 0,88 & 0,93 & 0,82 & 0,89 & 0,93 \\
Attitude Toward Digital & 0,78 & 0,94 & 0,95 & 0,76 & 0,93 & 0,95 \\
Campaign & & & & & & \\
Online W.O.M & 0,64 & 0,81 & 0,97 & 0,64 & 0,81 & 0,87 \\
Offline W.O.M & 0,67 & 0,87 & 0,91 & 0,69 & 0,89 & 0,92 \\
\hline
\end{tabular}

Tabel 4. Hasil analisis model struktural

\begin{tabular}{lcccccc}
\hline & \multicolumn{3}{c}{ Belum pernah $(\mathrm{n}=151)$} & \multicolumn{3}{c}{ Sudah pernah $(\mathrm{n}=202)$} \\
\cline { 2 - 6 } Hipotesis & $\begin{array}{c}\text { Standarize } \\
\text { Coefficient } \\
(\beta)\end{array}$ & $\mathrm{t}$ value & Keterangan & $\begin{array}{c}\text { Standarize } \\
\text { Coefficient } \\
(\beta)\end{array}$ & $\mathrm{t}$ value & Keterangan \\
\hline H1: Info -> AtiDC & 0,137 & 1,556 & Ditolak & 0,004 & 0,045 & Ditolak \\
H2: Entertmnt -> AtiDC & 0,243 & 2,538 & Diterima & 0,050 & 0,62 & Ditolak \\
H3: SelfCong -> AtiDC & 0,187 & 2,137 & Diterima & 0,404 & 4,641 & Diterima \\
H4: PeInf -> AtiDC & 0,298 & 2,420 & Diterima & 0,120 & 1,170 & Ditolak \\
H5: QtyLife -> AtiDC & $-0,169$ & 1,755 & Ditolak & $-0,170$ & 1,485 & Ditolak \\
H6: StcTime -> AtiDC & 0,004 & 0,058 & Ditolak & $-0,033$ & 0,348 & Ditolak \\
H7: Convi -> AtiDC & 0,110 & 1,129 & Ditolak & 0,429 & 5,133 & Diterima \\
H8: PriCon -> AtiDC & 0,138 & 1,717 & Diterima & 0,084 & 1,265 & Ditolak \\
H9: AtiDC -> e-WOM & 0,617 & 8,506 & Diterima & 0,612 & 13,461 & Diterima \\
H10: AtiDC -> WOM & 0,637 & 8,151 & Diterima & 0,676 & 16,674 & Diterima \\
\hline
\end{tabular}


Hasil Penelitian ini dijelaskan secara singkat pada Gambar 2. Pada kelompok yang belum pernah melihat kampanye sosial, dijelaskan bahwa motivasi terhadap pesan kampanye yang berpengaruh positif terhadap sikap pengguna pada kampanye sosial adalah entertainment dan self-brand congruity. Pada kelompok yang sudah pernah melihat hanya motivasi self-brand congruity yang berpengaruh positif. Dijelaskan lebih lanjut bahwa motivasi self-brand congruity memiliki pengaruh lebih besar dua kali lipat pada kelompok yang sudah pernah melihat kampanye dibandingkan yang belum pernah melihat kampanye. Hal tersebut dapat terjadi karena kelompok yang belum pernah melihat kampanye sosial belum mengetahui tentang konsep dan ide kampanye tersebut, sehingga terdapat motivasi lain untuk memengaruhi sikapnya terhadap kampanye sosial, yaitu motivasi entertainment. Dimana motivasi entertainment memiliki pengaruh yang lebih besar terhadap sikap pengguna yang belum pernah melihat kampanye sosial. Oleh karena itu, pesan kampanye sosial yang ditujukan pada kelompok yang belum pernah melihat kampanye sosial harus memiliki faktor entertainment dan self-brand congruity. Di pihak lain, pada kelompok yang sudah pernah melihat kampanye sosial, faktor self-brand congruity harus terdapat pada pesan kampanye.

Sikap pengguna terhadap kampanye sosial juga dipengaruh oleh motivasi pengguna untuk menggunakan media sosial. Pada Gambar 2 dijelaskan bahwa pada kelompok yang belum pernah melihat kampanye, motivasi peer influenced dan privacy concern yang berpengaruh positif terhadap sikap pengguna pada kampanye sosial. Sedangkan pada kelompok yang sudah pernah melihat kampanye sosial, hanya motivasi convenience yang berpengaruh positif. Dijelaskan lebih lanjut bahwa kelompok yang belum pernah melihat kampanye sosial, menjadikan kampanye sosial sebagai topik untuk berinteraksi dan bersosialisasi di media sosial. Hal tersebut sesuai dengan fungsi dasar dari media sosial, yaitu mempermudah pengguna untuk bersosilisasi dan berinteraksi dengan sesame pengguna (Williams et al. 2012). Akan tetapi, keamanan informasi privasi juga berpengaruh terhadap sikap pengguna yang belum pernah melihat kampanye sosial. Karena belum mengetahui sepenuhnya tentang kampanye tersebut. Pada kelompok yang sudah melihat kampanye, motivasi convenience satu-satunya yang berpengaruh dengan sikap pengguna terhadap kampanye sosial. Karena pengguna membutuhkan kenyamanan dan kemudahan untuk mengikuti atau mendukung kampanye tersebut.

Dalam media sosial pesan kampanye sosial dapat dikirim oleh siapa saja atau sumber yang tidak jelas, sehingga keabsahan atau keyakinan terhadap isi pesan tersebut sulit dibuktikan. Karena ketidakjelasan sumber tersebut, dapat berpengaruh pada kepercayaan akan informasi pada pesan kampanye sosial di media sosial dapat berkurang. Hal tersebut dapat menjadi penyebab tidak ada pengaruh antara motivasi informative dan sikap pengguna pada kampanye sosial. Karena indikator yang digunakan pada penelitian ini menjelaskan bahwa media sosial tempat yang penting dan cocok untuk mengetahui informasi terkini tentang kampanye stop illegal fishing.

Pada penelitian tidak mendukung bahwa motivasi quality of life berpengaruh positif terhadap sikap pengguna pada kampanye sosial. Dalam penelitian ini quality of life digambarkan sebagai peningkatan kualitas hidup dengan cara relaksasi untuk mengurangi stress. Dapat diasumsikan bahwa pengguna yang memiliki motivasi quality of life, seperti relaksasi, akan bersikap negatif terhadap kampanye sosial. Hal tersebut dapat disebabkan dari tujuan kampanye sosial yang dapat berpengaruh pada masyarakat dan lingkungan, karena kampanye tersebut termasuk dalam social marketing (Kotler dan Lee, 2011). Jika pengguna media sosial melihat pesan kampanye sosial pada saat relaksasi atau mengurangi tingkat stress, maka pengguna akan mengurangi sikapnya terhadap kampanye tersebut. Karena topik kampanye tersebut bersifat serius dan memungkinkan menambah tingkat stress. Selain itu dapat mengingatkan mereka terhadap dampak negatif dari kampanye stop illegal fishing. Selain itu pada penelitian ini tidak mendukung bahwa motivasi structured time berpengaruh terhadap sikap pengguna untuk kampanye sosial di media sosial. Walaupun pengguna mengakses media sosial secara rutin dan merupakan kebutuhan hidupnya, akan tetapi pesan kampanye sosial yang dapat dilihat tidak memengaruhi sikap pengguna tersebut terhadap kampanye sosial. Karena pengguna hanya fokus dalam menggunakan media sosial tersebut, dan tidak melakukan klasifikasi terhadap pesan-pesan pada timeline pengguna tersebut. Sehingga pengguna beranggapan bahwa pesan kampanye sosial hanya bagian dari media sosial yang sama dengan pesan-pesan yang lain (Taylor et al. 2011). 
Intensi untuk memberikan rekomendasi atau WOM dipengaruhi secara positif oleh sikap pengguna terhadap kampanye tersebut, baik untuk kelompok yang belum pernah dan sudah pernah melihat kampanye tersebut. Pengaruh sikap pengguna sedikit lebih besar pada offline WOM, dibandingkan pada online WOM. Oleh sebab itu untuk meningkatkan intensi pengguna untuk melakukan WOM maka dibutuhkan sikap yang positif terhadap kampanye tersebut, dimana sikap pengguna meningkat jika motivasi terhadap pesan kampanye dan penggunaan media sosial dapat terpenuhi oleh pesan kampanye sosial.

\section{Implikasi Manajerial}

Dari hasil penelitian ini, terdapat saran manajerial yang dapat digunakan oleh para tim kampanye, yaitu dua strategi yang dapat digunakan pada perumusan pesan kampanye di media sosial untuk mencari pendukung baru (acquiring) dan mempertahankan pendukung (retention) di media sosial. Pada strategi acquiring tim kampanye disarankan membuat pesan kampanye yang dapat menghibur atau menyenangkan pengguna media sosial. Pesan kampanye juga harus disesuaikan dengan pola pikir atau dapat mencerminkan jati diri pengguna yang ditargetkan. Oleh karena itu, pesan kampanye dapat menjadi bahan yang menarik untuk dijadikan topik pembicaraan. Selain itu tim kampanye harus dapat meyakinkan pengguna bahwa keamanan informasi privasi dijaga dengan baik.

Strategi kedua adalah retention, yang bertujuan menjaga pengguna media sosial untuk tetap tertarik pada kampanye stop illegal fishing. Adapun pesan kampanye harus sesuai dengan pola pikir pengguna media sosial yang ditargetkan. Menjaga kenyamanan para pengguna dengan cara mengatur jarak antara pesan kampanye sehingga tidak memenuhi timeline para pengguna.

\section{KESIMPULAN DAN SARAN}

\section{Kesimpulan}

Dari hasil penelitian ini dapat disimpulkan bahwa motivasi pengguna untuk menggunakan media sosial dan terhadap pesan kampanye terbukti secara signifikan berpengaruh positif pada sikap pengguna terhadap kampanye sosial di media sosial. Hal tersebut sesuai dengan beberapa penelitian sebelumnya yang menyatakan bahwa motivasi dari pengguna media sosial memengaruhi sikap pengguna tersebut (Taylor et al. 2011; Kim et al. 2011; Ha et al. 2015; Chung dan Austria, 2010; Chang danZhu, 2011; Celebi, 2015). Oleh karena itu, pesan kampanye sosial yang sesuai dengan motivasi pengguna dalm menggunakan media sosial, akan cenderung mendapatkan perhatian atau sikap yang positif dari para pengguna. Terdapat perbedaan motivasi antara kelompok pengguna yang belum pernah dan sudah pernah melihat kampanye stop illegal fishing di media sosial, dimana motivasi entertainment, selfbrand congruity, peer inlfuence, dan privacy concern yang memengaruhi sikap pengguna yang belum pernah melihat kampanye sosial. Sedangakan motivasi selfbrand congruity dan convenience yang memengaruhi sikap pengguna sudah pernah melihat kampanye sosial. Selengkapnya sebagai berikut:

1. Kelompok yang belum pernah melihat kampanye sosial (stop illegal fishing), motivasi terhadap pesan kampanye yang berpengaruh positif dengan sikap pengguna terhadap kampanye tersebut adalah entertainment dan self-brand congruity. Di pihak lain, untuk motivasi penggunaan media sosial yang berpengaruh adalah peer influenced, dan privacy concern. Oleh sebab itu, kampanye sosial harus dapat disesuaikan dengan motivasi tersebut, yaitu pesan harus dapat menghibur dan menyenangkan (Taylor et al. 2011; Chang dan Zhu, 2011; Lien dan Cao, 2014; Celebi, 2015), harus mencerminkan dengan self-image dari pengguna yang dijadikan target (Taylor et al. 2011; Celebi, 2015). Berikutnya pesan kampanye sosial harus menarik, sehingga pengguna dapat berinteraksi dan menceritakan tentang kampanye tersebut kepada teman-temannya (Taylor et al. 2011; Chung, 2015). Selain itu, kampanye sosial harus dapat menjaga keamanan infromasi privasi para pengguna (Stanaland et al. 2011; Celebi, 2015), dengan menjaga dan menggunakan informasi tersebut sesuai ketentuan. Hal tersebut untuk dapat menarik perhatian pengguna yang baru melihat pesan kampanye sosial tersebut.

2. Kelompok pengguna yang sudah pernah melihat kampanye sosial (stop illegal fishing), motivasi yang memengaruhi sikap pengguna terhadap kampanye tersebut adalah self-brand congruity dan convenience. Oleh karena itu, untuk tetap mendapatkan perhatian daripara penggunayang telah melihat, pesan kampanye harus tetap mencerminkan 
self-image para pengguna dan konsiten dengan pola pikir pengguna yang ditargetkan (Taylor et al. 2011; Celebi, 2015). Selain itu kampanye sosial di media sosial harus tetap memberi kenyamanan bagi para pengguna ketika menggunakan media sosial, sebaliknya pesan yang dapat mengganggu kenyamanan harus dihindari (Kim et al. 2011; Ha et al. 2015; Li et al. 2002; Ducoffe, 1996).

Dalam kampanye sosial (stop illegal fishing), intensi untuk memberikan rekomendasi (word of mouth), baik secara offline atau online, dipengaruhi oleh sikap pengguna terhadap kampanye tersebut. Oleh karena itu pengguna yang bersikap positif terhadap kampanye sosial akan cenderung memiliki intensi untuk memberikan rekomendasi tentang kampanya tersebut kepada orang lain. Hal tersebut sesuai dengan temuan pada penelitian sebelumnya yang menyetakan bahwa sikap positif berpengaruh positif terhadap pemberian WOM (Ha et al. 2013; Palka et al. 2009; Huang et al. 2012). Oleh karena itu, dengan menyesuaikan pesan kampanye sosial dengan motivasi pengguna dalam kampanye sosial di media sosial, dapat meningkatkan intensi untuk memberikan rekomendasi (WOM) secara tidak langsung. Sesuai dengan hasil temuan Lien dan Cao (2014) yang menjelaskan bahwa pemberian WOM dipengaruhi oleh motivasi pengguna, melalui mediasi sikap pengguna.

\section{Saran}

Selain itu saran untuk penelitian selanjutanya adalah mengidentifikasi perbedaan sikap pengguna media sosial berdasarkan perbedaan demografi pengguna (umur, jenis kelamin, tingkat pendididkan, dan lainlain). Selanjutnya, membandingkan sikap pengguna berdasarkan situs media sosial yang digunakan, misalnya sikap pengguna Facebook dan Twitter.

\section{DAFTAR PUSTAKA}

AdReaction. 2010. Brands + Consumers + Social Media: What Marketers Should Know About Who's Getting Social and Why. Dynamic Logic.

Ajzen I, Fishbein M. 1980. Understanding Attitudes and Predicting Social Behavior. Englewood Cliffs: Prentice-Hall.

Barker V. 2009. Older adolescents' motivations for social network site use: The influence of gender, group identity, and collective self-esteem.
CyberPsychology \& Behavior 12(2): 209-213.

Belch GE, Belch MA. 2003. Advertising and Promotion An Integreted Marketing Communication Perspective (6th ed). US: McGraw-Hill.

Camarero C，San José R. 2011. Social and attitudinal determinants of viral marketing dynamics. Computers in Human Behavior 27(6): 22922300.

Chang YP, Zhu DH. 2011. Understanding social networking sites adoption in China: A comparison of pre-adoption and post-adoption. Computers in Human behavior 27(5): 1840-1848.

Chu SC. 2009. Determinants of consumer engagement in electronics word-of-mouth in social networking sites [dissertation].Austin: University of Texas, Austin

Chung JE. 2015. Antismoking campaign videos on Youtube and audience response: Application of social media assessment metrics. Computers in Human Behavior 51:114-121.

Chung C, Austria K. 2010. Social Media Gratification and Attitude toward Social Media Marketing Messages: A Study of the Effect of Social Media Marketing Messages on Online Shopping Value. Proceedings of the Northeast Business \& Economics Association.

Ducoffe RH. 1996. Advertising value and advertising on the web. Journal of advertising research 36(5):21-35.

Goyette I, Ricard L, Bergeron J, Marticotte F. 2010. e-WOM Scale: word-of-mouth measurement scale for e-services context. Canadian Journal of Administrative Sciences 27(1):5-23.

Gresnews.com. 2014. Susi Pudjiastuti Ajak Masyarakat Kampanye Anti Ilegal Fishing di Dunia Maya. http://www.gresnews.com/berita/sosial/50312susi-pudjiastuti-ajak-masyarakat-kampanyeanti-illegal-fishing-di-dunia-maya/[21 Desember 2015].

Ha YW, Kim J, Libaque-Saenz CF, Chang Y, Park MC. 2015. Use and gratifications of mobile SNSs: Facebook and KakaoTalk in Korea.Telematics and Informatics 32(3):425-438.

Hair JF, Black WC, Babin BJ, Anderson RE, Tatham RL. 2006. Multivariate Data Analysis. Upper Saddle River, NJ: Pearson Prentice Hall.

Huang J, Su S, Zhou L, \& Liu X. 2013. Attitude toward the viral ad: expanding traditional advertising models to interactive advertising. Journal of Interactive Marketing 27(1): 36-46.

Hutton G, Fosdick M. 2011. The globalization of social 
media consumer relationships with brands evolve in digital space. Journal Advertising Research 51(4): 564-570.

Karahanna E, Straub DW, Chervany NL. 1999. Information technology adoption across time: a cross-sectional comparison of pre-adoption and post-adoption beliefs. MIS quarterly 183-213.

Kaplan AM, Haenlein M. 2010. Users of the world, unite! the challenges and opportunities of Social Media. Business horizons 53(1): 59-68.

Kassim N, Asiah Abdullah N. 2010. The effect of perceived service quality dimensions on Customer satisfaction, trust, and loyalty in e-commerce settings: a cross cultural analysis. Asia Pacific Journal of Marketing and Logistics 22(3):351-371.

Katz E, Blumler JG, Gurevitch M. 1974. Uses and gratifications research. Public opinion quarterly, 509-523.

Kemp S. 2015, Januari 21. Digital, Social, \& Mobile in 2015.http://wearesocial.sg/blog/2015/01/digitalsocial-mobile-2015/[21 Desember 2015].

Kim KS, Sin SCJ, Tsai T I. 2014. Individual differences in social media use for information seeking. The Journal of Academic Librarianship 40(2): 171178.

Kim Y, Sohn D, Choi SM. 2011. Cultural difference in motivations for using social network sites: A comparative study of American and Korean college students. Computers in Human Behavior 27(1): 365-372.

Krisanic K. 2008. Motivations and impression management: Predictors of social networking site use and user behavior. [Dissertation]. Columbia: University of Missouri.

Kotler P, Lee NR. 2011. Social marketing: Influencing Behaviors for Good (4rd Ed.). US: Sage Publications.

Ko H, Cho CH, Roberts MS. 2005. Internet uses and gratifications: A structural equation model of interactive advertising. Journal of advertising 34(2): 57-70.

Lassus C. 2003. Les Enfants et L'attitude Envers Le Site Web: Conception et Test D'une Echelle De Mesure. Centre De Recherche Dmsp, Cahier $\mathrm{N}^{\circ} 314$

Li H, Edwards SM, Lee JH. 2002. Measuring the intrusiveness of advertisements: Scale development and validation. Journal of Advertising 31(2): 37-47.
Lien CH, Cao Y. 2014. Examining WeChat users' motivations, trust, attitudes, and positive wordof-mouth: evidence from China. Computers in Human Behavior 41: 104-111.

Men LR, Tsai WHS. 2015. Infusing social media with humanity: corporate character, public engagement, and relational outcomes. Public Relations Review.

Mikalef P, Giannakos M, Pateli A. 2013. Shopping and word-of-mouth intentions on social media. Journal of theoretical and applied electronic commerce research 8(1): 1-34.

Okazaki S. 2009. The tactical use of mobile marketing: how adolescents' social networiking can best sliape brand extensions. Journal of Advertising Research 49(1):12-38

Okazaki S, Li H, Hirose M. 2009. Consumer privacy concerns and preference for degree of regulatory control. Journal of Advertising 38(4): 63-77.

Palka W, Pousttchi K, Wiedemann DG. 2009. Mobile word-of-mouth-a grounded theory of mobile viral marketing. Journal of Information Technology 24(2): 172-185.

Papacharissi Z, Rubin AM. (2000). Predictors of internet use. Journal of Broadcasting \& Electronic Media, 44(2): 175-196.

Powers T, Advincula D, Austin MS, Graiko S, Snyder J. 2012. Digital and social media in the purchase decision process a special report from the advertising research foundation. Journal of advertising research 52(4): 479-489.

Solomon MR. 2013. Consumer Behavior: Buying, Having and Being. 10th edition. London: Prentice Hall

Stanaland AJ, Lwin MO, Miyazaki A. 2011. Online privacy trustmarks: enhancing the perceived ethics of digital advertising. Journal of Advertising Research (51):511-523.

Taylor DG, Lewin JE, Strutton D. 2011. Friends, fans, and followers: do ads work on social networks?. Journal of Advertising Research 51(1): 258275.

Thackeray R, Neiger BL, Hanson CL, McKenzie JF. 2008. Enhancing promotional strategies within social marketing programs: use of web 2.0 social media. Health promotion practice 9(4):338343.

Whiting A, Williams D. 2013. Why people use social media: a uses and gratifications approach. Qualitative Market Research: An International 
Journal 16(4): 362-369.

Williams DL, Crittenden VL, Keo T, McCarty P. 2012. The use of social media: an exploratory study of usage among digital natives. Journal of Public Affairs 12(2): 127-136.

Williamson A, Miller L, Fallon F. 2010. Behind the
Digital Campaign. An Exploration of the Use, Impact and Regulation of Digital Campaigning. London: Hansard Society.

Wojnicki AC, Godes D. 2008. Word-of-mouth as selfenhancement. HBS marketing research paper 06-01. 